\title{
PERILAKU KEPATUHAN DIET DAN AKTIVITAS FISIK TERHADAP PENGENDALIAN KADAR GULA DARAH PASIEN DIABETES MELLITUS TIPE II
}

\author{
Nonce Nova Legi ${ }^{1}$, Ana B. Montol ${ }^{2}$ Grace K.L.Langi ${ }^{3}$, Selvian Soplanit ${ }^{4}$ \\ Jurusan Gizi Poltekkes Kemenkes Manado
}

\begin{abstract}
Diabetes Mellitus is a disorder of metabolism of carbohydrates, proteins and fats resulting from an imbalance between the availability of insulin and insulin requirements. se of this study was to determine the relationship of diet adherence and physical activity with controlling blood sugar levels in patients with type II diabetes mellitus outpatient at the Manado Radiation Hospital.

This study was an observational analytic study with a cross sectional design. The population in this study were all Diabetes Mellitus Type II outpatients in the hospital. Pancaran Kasih Manado The number and sample are 39 people and the sample is determined by purposive sampling.

The test results between the relationship of diet adherence with blood sugar levels obtained a $p$-value of 0.670 , meaning that there was no significant relationship between the variables of diet compliance with blood sugar levels. While physical activity with blood sugar levels get a p-value of 0.499 , it means there is no significant relationship between physical activity variables with blood sugar levels.

The conclusion of this study is that there is no significant relationship between adherence to diet, physical activity with controlling blood sugar levels in patients with type 2 Diabetes Mellitus in the hospital Radiation of Love Manado.
\end{abstract}

Keywords: Diabetes Mellitus type 2, physical activity, diet compliance, blood sugar level

\section{PENDAHULUAN}

Penyakit degeneratif adalah penyakit yang menyebabkan terjadinya kerusakan atau penghancuran terhadap jaringan atau organ tubuh, kerusakan ini dapat disebabkan oleh penggunaan seiring dengan usia maupun pola hidup yang tidak sehat. Salah satu contoh penyakit yang termasuk dalam klasifikasi penyakit degeneratif yaitu Diabetes Mellitus. Diabetes Mellitus adalah suatu gangguan metabolisme karbohidrat, protein dan lemak akibat dari ketidak seimbangan antara ketersediaan insulin dengan kebutuhan insulin. Dikutip dalam Awad dkk, (2011) pada tahun 2003, World Health Organisation (WHO) memperkirakan 194 juta atau 5,1\% dari 3,8 milyar penduduk dunia usia 20-79 tahun menderita Diabetes Mellitus dan diperkirakan pada tahun 2025 akan meningkat menjadi 333 juta. Di tahun yang sama International Diabetes Federation (IDF) menyebutkan bahwa prevalensi Diabetes Mellitus di dunia adalah 1,9\% dan telah menjadikan Diabetes Mellitus sebagai penyebab kematian urutan ke tujuh di dunia.

Berdasarkan Hasil Riset Kesehatan Dasar, prevalensi Diabetes Mellitus pada tahun 2013 di Indonesia yaitu sebesar 1,5\% berdasarkan jawaban didiagnosis dokter, dan sebesar $2,1 \%$ berdasarkan diagnosis/gejala. Prevalensi tertinggi di daerah Jawa Tengah yaitu sebesar 3,7\% dan Sulawesi Utara 3,6\% . 
Dari laporan Riskesdas Sulawesi Utara tahun 2013, prevalensi Diabetes Mellitus tertinggi di daerah Kota Tomohon (5,6\%) dan terendah di daerah Minahasa Selatan (1,3\%). Di kota Manado sendiri prevalensi Diabetes Mellitus yaitu sebesar 3,8 \% menempati urutan ke-6 tertinggi bersama dengan daerah Minahasa Tenggara (Balitbangkes, 2013).

Penatalaksanaan diet bagi penderita Diabetes Mellitus sendiri tentu harus tetap diberikan asupan zat gizi yang seimbang, memperhatikan kadar glukosa darah pada kondisi normal, serta memenuhi kebutuhan pasien, untuk itu pemberian diet bagi pasien Diabetes Mellitus harus memperhatikan jumlah, jenis, dan jadwal. Hasil penelitian yang dilakukan oleh Susanti dan Sulistyarini (2013) didapat bahwa dukungan keluarga dapat meningkatkan kepatuhan diet pasien diabetes mellitus. Selain kepatuhan terhadap diet, ada juga hal-hal yang dapat membantu untuk mengendalikan kadar gula darah, salah satunya yaitu dengan aktivitas fisik. Aktivitas fisik merupakan gerakan fisik yang dilakukan oleh otot tubuh dan sistem penunjangnya, dalam penyakit Diabetes Mellitus aktivitas fisik menjadi bagian penentu indeks glukosa karena didalam seseorang melakukan aktivitas fisik baik yang ringan, sedang, ataupun berat akan membutuhkan kalori atau energi.

Tujuan penelitian ini untuk mengetahui bagaimana hubungan kepatuhan diet dan aktivitas fisik dengan pengendalian kadar gula darah pasien Diabetes Mellitus tipe II rawat jalan di rumah sakit pancaran kasih manado. Tujuan khusus dalam penelitian untuk mengetahui tingkat kepatuhan pasien Diabetes Mellitus Tipe II rawat jalan di Rumah Sakit Pancaran Kasih Manado dalam menjalani diet, mengetahui bagaimana tingkat aktifitas fisik pasien Diabetes Mellitus Tipe II rawat jalan di Rumah Sakit Pancaran Kasih Manado, mengetahui hubungan kepatuhan diet dengan pengendalian kadar gula darah pasien Diabetes Mellitus tipe II di Rumah Sakit Pancaran Kasih Manado, dan mengetahui hubungan aktivitas fisik dengan pengendalian kadar gula darah pasien Diabetes Mellitus tipe II di Rumah Sakit Pancaran Kasih Manado

\section{BAHAN DAN CARA}

Penelitian ini dilaksanakan di Rumah Sakit Pancaran Kasih Manado. Waktu penelitian dilaksanakan pada bulan April 2017. Jenis penelitian ini adalah observasional analitik dengan desain yang dilakukan adalah cross sectional (potong lintang). Variabel dalam penelitian terdiri dari variabel bebas yaitu kepatuhan diet dan aktivitas fisik dan variabel terikat yaitu kadar gula darah.

Sampel dalam penelitian ini adalah pasien Diabetes Mellitus Tipe II rawat jalan di Rumah Sakit Pancaran Kasih Manado, yang pernah datang berkunjung dan menerima terapi diet. Jumlah sampel yaitu 39 orang dan sampel ditentukan secara purposive sampling. Bersedia menandatangani informed consent, bersedia untuk dilakukan wawancara, dapat berkomunikasi dengan baik, tidak dalam keadaan hamil. Instrumen yang digunakan dalam penelitian ini adalah kuesioner untuk mengambil data umum yang meliputi data, jenis kelamin, umur, agama, pendidikan, serta pekerjaan responden. Untuk mengukur kepatuhan diet responden diambil dengan menggunakan kuesioner, untuk aktivitas fisik digunakan Internasional physical activity questionnaire (IPAQ) dan untuk pemeriksaan kadar gula darah responden diukur dengan menggunakan alat Gluco dr dengan bantuan dari enumerator.

Pengolahan dan analisis data statistic diawali dengan melakukan editing dan coding data untuk memudahkan proses pemasukan data, kemudian 
dilanjutkan dengan mengentri data pada program software statistic. Analisis bivariate yaitu untuk mengetahui hubungan perilaku kepatuhan diet dan aktivitas fisik dengan pengendalian kadar gula darah dengan menggunakan uji spearman rho.

\section{HASIL}

Hasil penelitian menunjuk-kan bahwa sebagian besar responden berjenis kelamin wanita yaitu sebanyak 31 orang (79.5\%); Sedangkan usia responden yang paling banyak yaitu berkisar antara 46 - 55 tahun dengan jumlah 20 orang (51.2\%). Adapun pekerjaan responden sebagian besar yaitu ibu rumah tangga (IRT) dengan persentase $51.2 \%$, dan yang terendah adalah petani dan buruh/tukang dengan jumlah responden masing-masing 1 responden (2.6\%).

1. Kepatuhan Diet

Tabel 1. Distribusi Subjek Menurut Klasifikasi Kepatuhan Diet

\begin{tabular}{ccc}
\hline Kepatuhan & $\mathrm{n}$ & $\%$ \\
\hline Patuh & 37 & 94.8 \\
Tidak Patuh & 2 & 5.1 \\
\hline Total & 39 & 100 \\
\hline
\end{tabular}

Berdasarkan tabel di atas, dari 39 responden terdapat 2 orang yang tidak patuh terhadap diet dengan persentase $5.1 \%$ dan terdapat 37 orang yang patuh terhadap diet dengan persentase $94.8 \%$.

2. Aktifitas Fisik

Tabel 2. Distribusi Subjek Menurut Klasifikasi Aktivitas Fisik

\begin{tabular}{ccc}
\hline Klasifikasi Aktivitas Fisik & $\mathrm{n}$ & $\%$ \\
\hline Aktivitas Ringan & 12 & 30.7 \\
Aktivitas Sedang & 26 & 66.7 \\
Aktivitas Berat & 1 & 2.6 \\
\hline Total & 39 & 100 \\
\hline
\end{tabular}

Berdasarkan tabel di atas dapat disimpulkan bahwa responden dalam penelitian ini lebih banyak memiliki aktivitas sedang dengan jumlah responden 26 responden dengan persentase $66.7 \%$ dan untuk aktivitas berat memiliki 1 responden dengan persentase $2.6 \%$. 
3. Kadar Gula Darah

Tabel 3. Distribusi Subjek Menurut Klasifikasi Kadar Gula Darah

\begin{tabular}{ccc}
\hline Kadar Gula Darah & $\mathrm{n}$ & $\%$ \\
\hline Terkendali & 24 & 61.5 \\
Tidak Terkendali & 15 & 38.5 \\
\hline Total & 39 & 100 \\
\hline
\end{tabular}

Berdasarkan tabel di atas, dalam penelitian ini kadar gula darah responden yang tidak terkendali dengan jumlah responden 15 orang dengan persentase $38.5 \%$ dan 24 orang memiliki kadar gula darah yang terkendali dengan persentase $61.5 \%$.

4. Hubungan Kepatuhan Diet Dengan Pengendalian Kadar Gula Darah

Tabel 4. Hasil Uji Korelasi Spearman Kepatuhan Diet

\begin{tabular}{cccccc}
\hline \multirow{2}{*}{ Kepatuhan Diet } & \multicolumn{3}{c}{ Kadar Gula Darah } & \multirow{2}{*}{ Nilai } \\
\cline { 2 - 4 } & \multicolumn{2}{c}{ Terkendali } & \multicolumn{1}{c}{ Tidak Terkendali } & p-value \\
\cline { 2 - 4 } & $\mathrm{n}$ & $\%$ & $\mathrm{n}$ & $\%$ & \\
\hline Patuh & 23 & 58.9 & 14 & 35.9 & \multirow{2}{*}{0.670} \\
Tidak Patuh & 1 & 2.6 & 1 & 2.6 & \\
\hline Total & 24 & 61.5 & 15 & 38.5 & \\
\hline
\end{tabular}

Dari data di atas, diketahui nilai signifikan atau Sig. (2-tailed) sebesar 0.670, karena nilai Sig. (2-tailed) $0.670>$ lebih besar dari 0.05 maka artinya tidak ada hubungan yang signifikan antara variabel kepatuhan diet dengan kadar gula darah.

5. Hubungan Aktivitas Fisik Terhadap Pengendalian Kadar Gula Darah

Tabel 5. Hasil Uji Korelasi Spearman Aktivitas Fisik

\begin{tabular}{lccccc}
\hline \multirow{2}{*}{ Aktivitas Fisik } & \multicolumn{4}{c}{ Kadar Gula Darah } & \multirow{2}{*}{ Nilai } \\
\cline { 2 - 5 } & \multicolumn{3}{c}{ Terkendali } & Tidak Terkendali & p-value \\
\cline { 2 - 5 } & $\mathrm{n}$ & $\%$ & $\mathrm{n}$ & $\%$ & \\
\hline Aktivitas Ringan & 3 & 7.7 & 9 & 23.1 & \\
Aktivitas Sedang & 6 & 15.4 & 20 & 51.3 & \multirow{2}{*}{0.499} \\
Aktivitas Berat & 0 & 0 & 1 & 2.5 & \\
\hline \multicolumn{1}{c}{ Total } & 9 & 23.1 & 30 & 76.9 & \\
\hline
\end{tabular}

Dari tabel 9 di atas, dapat dilihat nilai signifikan atau Sig. (2-tailed) sebesar 0.499 , karena nilai Sig. (2-tailed) 0.499 > lebih besar dari 0.05 maka artinya tidak ada hubungan yang signifikan antara variabel aktivitas fisik dengan kadar gula darah. 


\section{PEMBAHASAN}

1. Kepatuhan Diet

Berdasarkan tabel 5, diketahui dalam penelitian ini dari 39 responden patuh terhadap diet dengan jumlah 37 orang (94.8\%) dan yang tidak patuh dengan jumlah 2 orang $(5.1 \%)$. Kepatuhan pasien Diabetes Mellitus dalam melaksanakan diet merupakan salah satu hal terpenting dalam pengendalian Diabetes Mellitus. Kepatuhan diet adalah faktor penting dalam menjalankan diet sehingga kadar glukosa dalam darah dapat terkontrol. Dalam penelitian ini, responden yang patuh lebih banyak dari responden yang tidak patuh, ini disebabkan karena para responden telah mengerti dan mengetahui hal-hal apa saja yang perlu diperhatikan pada orang yang menderita penyakit Diabetes Mellitus, selain itu juga karena kebanyakan responden yang menderita penyakit Diabetes Mellitus di Rumah Sakit Pancaran Kasih Manado merupakan penderita yang sudah lama menderita penyakit Diabetes Mellitus.

\section{Aktivitas Fisik}

Berdasarkan tabel 6 di dapat bahwa dalam penelitian ini responden lebih banyak memiliki aktivitas sedang dengan jumlah responden 26 orang $(66.7 \%)$, sedangkan untuk responden yang memiliki aktivitas sedang berjumlah 12 orang $(30.8 \%)$ dan responden yang memiliki aktivitas berat berjumlah 1 orang $(2.6 \%)$. Aktivitas fisik merupakan kunci pengelolaan diabetes secara medis, selain diet dan pengobatan/insulin yang tepat. Menurut Plotnikoff (2006) dalam Canadian Journal of Diabetes, aktivitas fisik merupakan kunci dalam pengelolaan diabetes melitus terutama sebagai pengontrol gula darah dan memperbaiki faktor resiko kardiovaskuler seperti menurunkan hiperinsulinemia, meningkatkan sesnsitifitas insulin, menurunkan lemak tubuh, serta menurunkan tekanan darah. Dalam penelitian ini aktivitas fisik responden lebih banyak memiliki aktivitas sedang hal ini dimungkinkan karena responden dalam penelitian ini lebih banyak para ibu rumah tangga yang berpartisipasi.

\section{Hubungan Perilaku Kepatuhan Diet Terhadap Pengendalian Kadar Gula Darah}

Dari hasil penelitian, di peroleh hasil yaitu responden yang patuh terhadap diet dan memliki kadar gula darah yang terkendali yaitu sebanyak 23 orang, sedangkan yang patuh tetapi memiliki kadar gula darah yang tidak terkendali yaitu 14 orang. Untuk responden yang tidak patuh tetapi memiliki kadar gula darah yang terkendali yaitu 1 orang dan yang tidak patuh tetapi memiliki kadar gula darah yang tidak terkendali yaitu 1 orang. Hasil uji statistik dengan menggunakan spearman di dapat nilai signifikan atau Sig. (2-tailed) sebesar 0.670, karena nilai Sig. (2-tailed) 0.670 > lebih besar dari 0.05 maka artinya tidak ada hubungan yang signifikan antara variabel kepatuhan diet dengan kadar gula darah.

Penelitian ini menunjukan bahwa tidak ada hubungan kepatuhan diet dengan kadar gula darah, hal ini sejalan dengan penelitian yang dilakukan oleh Ernaeni (2005) yang menyatakan bahwa tidak terdapat hubungan yang signifikan antara kepatuhan diet dengan kadar gula darah dengan nilai $p$-value 0.890 . 
4. Hubungan Aktivitas Fisik Terhadap Pengendalian Kadar Gula Darah

Dalam penelitian ini, di peroleh bahwa responden yang memiliki aktivitas ringan dan memiliki kadar gula darah yang terkendali yaitu 3 orang dan yang tidak terkendali yaitu 9 orang, untuk responden yang memiliki aktivitas sedang dan memiliki kadar gula darah yang terkendali yaitu 6 orang dan yang tidak terkendali yaitu 20 orang, dan untuk responden yang memiliki aktivitas berat yaitu 1 orang dan memiliki kadar gula darah yang tidak terkendali.

Hasil dari penelitian ini menunjukan bahwa tidak ada hubungan yang signifikan antara variabel aktivitas fisik dengan kadar gula darah, dengan hasil nilai $p$-value 0.499 yang menunjukan nilai $p$-value 0.499 > lebih besar dari 0.05 . $\mathrm{Hal}$ ini sejalan dengan penelitian yang dilakukan oleh Nur, dkk (2016) menyatakan bahwa tidak terdapat hubungan yang signifikan antara aktivitas fisik dengan kadar gula darah pasien. Selain itu penelitian yang dilakukan oleh Hariyanto (2013) juga menyatakan bahwa tidak terdapat hubungan antara aktivitas fisik dengan kadar gula darah dengan nilai $p$-value 0.495 .

Hasil penelitian yang menunjukan bahwa tidak terdapat hubungan antara aktivitas fisik terhadap pengendalian kadar gula darah, hal ini kemungkinan disebabkan karena para responden memiliki aktivitas yang berbeda-beda, dan dalam penelitian ini responden lebih banyak memiliki aktivitas sedang yang dimana dalam hal ini responden ibu rumah tangga.

\section{Kelemahan Penelitian}

Kelemahan dalam penelitian ini yaitu, peneliti tidak melakukan recall untuk menentukan tingkat kepatuhan responden melainkan peneliti menggunakan kuesioner kepatuhan diet untuk mengukur tingkat kepatuhan responden sehingga dapat dikatakan tidak efektif untuk menentukan tingkat kepatuhan responden. Selain itu dalam penelitian ini juga responden merupakan pasien Diabetes Mellitus yang telah mengkonsumsi obat.

\section{KESIMPULAN}

1. Kepatuhan diet responden sebagian besar patuh pada diet yang diberikan yaitu sebanyak 37 orang (94.8\%).

2. Aktivitas fisik responden sebagian besar memiliki aktivitas sedang yaitu sebanyak 26 orang $(66.7 \%)$,

3. Kepatuhan diet terhadap pengendalian kadar gula darah tidak ada hubungan yang signifikan, dimana nilai Sig. (2-tailed) sebesar $0.670>$ lebih besar dari 0.05 .

4. Aktivitas fisik terhadap pengendalian kadar gula darah tidak ada hubungan yang signifikan dimana nilai Sig. (2-tailed) sebesar $0.499>$ lebih besar dari 0.05 .

\section{SARAN}

1. Perlu lagi ditingkatkan pengetahuan dan bimbingan bagi para penderita Diabetes Mellitus tipe 2 agar lebih mematuhi diet yang diberikan sehingga kadar gula darah dapat terkendali.

2. Bagi Rumah Sakit Pancaran Kasih sebaiknya dapat memberikan konseling terhadap pasien terkait pentingnya perilaku patuh terhadap diet dan untuk meningkatkan aktivitas fisik pasien. 


\section{DAFTAR PUSTAKA}

Afifa (2014). Makalah Glukosa Darah. www//ifaphiyaphiyo.blogspot.co.id. diakses 12 mei 2016

Awad, N. Langi, Y.A. \& Pandelaki, K. (2011). Gambaran Faktor Resiko Pasien Diabetes Melitus Tipe II di Poliklinik Endokrin Bagian/SMF FK-UNSRAT RSU Prof.Dr. R.D Kandou Manado Periode Mei 2011- Oktober 2011. Jurnal e.Biomedic. Volume 1, Nomor 1, halaman 45-49.

Ayu, K. Priyanto. \& Wakhid, A. (2013). Hubungan Kepatuhan Diet Dengan Kadar Glukosa Darah Sewaktu Pada Pasien Daibetes Mellitus Tipe 2 Di Klinik Pratama Gracia Ungaran Kabupaten Semarang.

Badan Penelitian dan Pengembangan Kesehatan Departemen Kesehatan. Laporan Riset kesehatan dasar. Jakarta: Balitbangkes; 2013.

Badan penelitian dan pengembangan kesehatan (2013). Pokok-pokok hasil riset kesehatan dasar. Sulawesi Utara

Dalimartha, Setiawan. \& Adrian, Felix. (2014). Makanan \& Herbal Untuk Penderita Diabetes Melitus. Penebar Swadaya, Jakarta Timur.

Damayanti, Santi. (2015). Diabetes Mellitus \& Penatalaksanaan Keperawatan. Nuha Medika, Yogyakarta.

Eko, Akhmad. (2010). Hubungan Aktivitas Fisik Dan Istirahat Dengan Kadar Gula Darah Pasien Diabetes Mellitus Rawat Jalan RSUD. Prof. DR. Margono Soekardjo. Program Studi Ilmu Keperawatan Universitas Muhammadiyah, Purwokerto.

Ernaeni. (2005). Hubungan Kepatuhan Diet Dengan Pengendalian Kadar Gula Darah.Banyumanik Semarang

Fakultas Kedokteran Universitas Indonesia. (2007). Penatalaksanaan Diabetes Mellitus Terpadu. Balai Penerbit FKUI, Jakarta.

Febriana, R. (2014). Hubungan Kepatuhan Diit Dengan Kadar Gula Darah Sewaktu Pada Pasien Diabetes Melitus Tipe II Di Rawat Inap RSUD Sukoharjo. Fakultas Kedokteran Universitas Muhammadyah Surakarta.

Fitriyani. (2012). Faktor resiko Diabetes Melitus Tipe 2 di puskesmas kecamatan citangkil dan puskesmas kecamatan pulo merak kota cilegon. Fakultas Kesehatan Masyarakat. Depok.

Hariyanto, F. (2013). Hubungan Aktivitas Fisik Dengan Kadar Gula Darah Puasa Pada Pasien Diabetes Mellitus Tipe 2 Di Rumah Sakit Umum Daerah Kota Cilegon.

Indarwati, D. Riskinia. Rusmariana. Hartanti, R.D. (2012). Hubungan Motivasi Dengan Kepatuhan Diet Diabetes Melitus Pada Pasien Diabetes Melitus Pada Pasien Diabetes Melitus Di Desa Tangkil Wilayah Kerja Puskesmas Kedungwuni II Kabupaten Pekalongan. Jurnal Stikes.

Katsilambros, N. Dimosthenopoulos, C. Kontogianni, M. Manglara, E. dan Poulia, K.A. (2010). Asuhan Gizi Klinik. Kedokteran EGC. Jakarta

Kolibu, M. Meity. (2010). Hubungan Asupan Zat Gizi Dan Status Gizi Dengan Kadar Gula Darah Pasien Diabetes Melitus Tipe II Di Poliklinik Gizi BLU RSUP Prof. Dr R.D Kandou Manado. Pendidikan Diploma IV Kesehatan. Jurusan Gizi Politeknik Kesehatan Manado.

Kurniadi, H. \& Nurrahmani, U. (2014). Stop Diabetes Hipertensi Kolesterol Tinggi Jantung Koroner. Istana Media, Yogyakarta.

Kusumawati, I. (2014). Kepatuhan Menjalani Diet Ditinjau Dari Jenis Kelamin Dan Tingkat Pendidikan Pada Penderita Diabetes Melitus Tipe 2. Fakultas Psikologi Universitas Muhammadiyah Surakarta. 
Maryunani, A. (2008). Buku Saku Diabetes Pada Kehamilan. CV Trans Info Media, Jakarta.

Maulah, I. (2013). Hubungan Lama Pendidikan dan Persepsi Pasien Tentang Diet Dengan Kepatuhan Diet Pasien Diabetes Mellitus Tipe II Rawat Inap Di RS PKU Muhammadiyah Surakarta. Fakultas IImu Kesehatan Universitas Muhammadiyah Surakarta.

Nur, A. Wilya, W. \& Ramadhan, R. (2016). Kebiasaan Aktivitas Fisik Pasien Diabetes Mellitus Terhadap Kadar Gula Darah Di Rumah Sakit Umum dr. Fauziah Bireuen. Loka Litbang Biomedis Aceh.

Oktanita, R. t.t . Kuesioner-Kepatuhan-Dalam-Menjalani-Diet-Pasien-DiabetesMelitus. www.scribd.com/doc/220054042/ diakses tanggal 26 april 2016 $10.37 \mathrm{am}$

Pakaya, M. (2014). Analisis Faktor-faktor Yang MEempengaruhi Kadar Glukosa Darah Pada Diabetisi Tipe 2 Rawat Jalan Di Poli Endokrin Badan Layanan Umum (BLU) RSUP PROF DR. R.D. Kandou Manado. Diploma IV Jurusan Gizi Politeknik Kesehatan Manado.

Paramitha, G.M. (2014). Hubungan Aktivitas Fisik Dengan Kadar Gula Darah Pada Pasien Diabetes Mellitus Tipe 2 Di Rumah Sakit Umum Daerah Karanganyar. Fakultas Kedokteran Universitas Muhammadiyah Surakarta.

Perkeni.(2011). Konsensus Pengendalian dan Pencegahan Diabetes Melitus Tipe 2 di Indonesia 2011.

Pertiwi, R. A. (2016). Hubungan Aktivitas Fisik Dengan Kadar Glukosa Darah Puasa Pada Pasien Diabetes Mellitus Tipe 2 Di Denpasar Selatan. Fakultas Kedokteran Program Studi Pendidikan Dokter Universitas Udayana.

Plotnikoff, R. C., 2006. Physical Activity in the Management of Diabetes: Population-based Perspectives and Strategies. Canadian Journal of Diabetes.

Saryono. (2011). Metodologi Penelitian Kesehatan. Mitra Cendikia Press, Jogjakarta.

Setyani, T. (2012). Hubungan Tingkat Depresi Dengan Kadar Gula Darah Pada Penderita Diabetes Mellitus Tipe II Di Rumah Sakit Umum Daerah Karanganyar.

Suiroka, IP. 2012. Penyakit Degeneratif. Yogyakarta. Nuha Medika

Susanti, M.L. \& Sulistyarini, T. (2013). Dukungan Keluarga Meningkatkan Kepatuhan Diet Pasien Diabetes Melitus Di Ruang Rawat Inap RS. Baptis Kediri. Jurnal Stikes.

Qurratuaeni. (2009). Faktor-faktor yang berhubungan Dengan Terkendalinya Kadar Gula Darah Pada Pasien Diabetes Mellitus Di Rumah Sakit Umum Pusat Fatmawati. Fakultas Kedokteran dan IImu Kesehatan. UIN Syarif Hudayatullah, Jakarta.

Widyastuti, W. (2012). Hubungan Antara Depresi Dengan Kepatuhan Melaksanakan Diit Pada Diabetisi Di Pekalongan. Jurnal IImiah Kesehatan. Volume IV Nomor 1. 